\title{
Occurrence of Multiple Albumins in Carp Blood Plasma*1
}

\author{
Tadashi YanAgiSAWA ${ }^{* 2}$, Kanehisa HaShimoto*2, \\ and Fumio MatsuUra*3 \\ (Received May 4, 1977)
}

\begin{abstract}
Five albumin components designated $S_{2} D_{1}, S_{2} D_{2}, S_{3} E_{1}, S_{3} E_{2}$, and $S_{3} E_{3}$, were isolated from carp plasma by a combination of Sephadex G-200 gel filtration, DEAE-cellulose column chromatography, and preparative electrophoresis. Their molecular weights, in the above order, were estimated to be $145,000,145,000,58,000,71,000$, and 71,000 , respectively. It was demonstrated that each of components $S_{2} D_{1}$ and $S_{2} D_{2}$ is composed of several subunit chains, while each of the remaining components constitutes a single chain. Results of the dye binding tests showed that only components $S_{2} D_{1}$ and $S_{2} D_{2}$ bind with $B P B$, though all five components bind with HABA and BCG. Component $\mathrm{S}_{3} \mathrm{E}_{2}$ showed the strongest BCG-binding ability. All the components except $S_{3} E_{1}$ exhibited methemalbumin forming ability. Components $S_{3} E_{1}$ and $S_{3} E_{2}$ showed Sevin esterase activity. It was noted that component $S_{3} E_{2}$ is highest in these activities.
\end{abstract}

The blood plasma proteins of fish have so far been characterized less satisfactorily than those of the mammalian origin, especially of human ${ }^{1-3)}$. Recently, attempts to classify the plasma proteins of several fishes have been made mainly from the viewpoint of comparative biochemistry ${ }^{4,5}$. However, even with carp, the fish whose plasma proteins have been examined most intensively ${ }^{6-9}$, much remain to be elucidated.

The present study was undertaken to characterize further the plasma albumin of carp. The results showed that unlike the mammalian albumin, carp albumin is composed of a number of components, each one sharing with other ones various physiological functions.

\section{Materials and Methods}

Materials The blood was individually collected by heart puncture from the cultured specimens (av. body weight: $800 \mathrm{~g}$ ) of the carp Cyprinus carpio. Heparin was used as the anticoagulant. The blood samples were centrifuged to separate the plasma from the red cells. Non-hemolyzed plasmas were combined and immediately used for the following experiments. A portion of the red cell cake was repeatedly washed with the physiological saline and kept frozen below $-20^{\circ} \mathrm{C}$ after being mixed with an approximately equal volume of the glycerin-citrate mixture ${ }^{10)}$. The hemolyzate was prepared as usual from the red cells and used for examining the methemalbumin forming ability of plasma albumin as described below.

*1 Read before Annual Meeting of the Japan. Soc. Sci. Fish. held in Tokyo on Apr. 2, 1975.

*2 Lab. of Marine Biochem., Fac. of Agr., The Univ. of Tokyo, Bunkyo-ku, Tokyo (柳沢 忠 - 橋本 周久: 東京大学苌学部).

*3 School of Fish. Sci., Kitasato Univ., Sanriku, Iwate (松浦文雄：北里大学水産学部). 
The blood plasma and red cell hemolyzate of rabbit were similarly provided and used as the control.

Fractionation of plasma proteins Portions of carp plasma were 1/3-, 1/2-, and 2/3saturated with ammonium sulfate at $\mathrm{pH} 7.0$. The protein concentration in the mixture was fixed at $10-12 \mathrm{mg} / \mathrm{ml}$. The mixtures were gently stirred overnight at $2-4^{\circ} \mathrm{C}$, followed by centrifugation at $1,000 \times \mathrm{g}$ for $30 \mathrm{~min}$ or by filtration. The supernatants were then desalted by dialysis, concentrated by ultrafiltration with Amicon XM-50 up to $30 \mathrm{mg} / \mathrm{m} l$. The fractions thus provided were analyzed electrophoretically. The plasma protein fractions of rabbit were similarly prepared and analyzed.

The carp plasma proteins were also salted out with sodium sulfate at $13.5,17.4$, and $21.5 \%$ at $\mathrm{pH} 7.0$ in almost the same procedures as above. The supernatants obtained were concentrated after dialysis and analyzed electrophoretically.

Isolation of albumin components After various preliminary experiments, carp albumin components were isolated by the method which consisted of Sephadex G-200 gel filtration, DEAE-cellulose column chromatography, and starch block electrophoresis. All the operations were carried out in a cold room at $2-4^{\circ} \mathrm{C}$, unless otherwise stated.

Sephadex $G-200$ gel filtration Twenty $\mathrm{m} l$ of carp plasma was loaded onto a Sephadex G-200 column $(5 \times 100 \mathrm{~cm})$ which was preequilibrated with $0.1 \mathrm{M}$ Tris- $\mathrm{HCl} \mathrm{pH} 8.0$ containing $0.5 \mathrm{M} \mathrm{NaCl}$ and $0.1 \% 2$-mercaptoethanol ${ }^{12)}$. The same mixture was used as the solvent at a flow rate of $30 \mathrm{~m} l / \mathrm{hr}$. The upward system was adopted. Ten-m $l$ fractions were collected and monitored at $280 \mathrm{~nm}$.

DEAE-cellulose column chromatography Fraction $\mathrm{S}_{2}$, as separated by Sephadex gel filtration (Fig. 2), was dialyzed against $5 \mathrm{~mm}$ phosphate buffer $\mathrm{pH} 7.2$, and chromatographed on a DEAE-cellulose column $(2 \times 30 \mathrm{~cm})$ by a linear gradient, using $200 \mathrm{ml}$ each of the above phosphate buffer and $50 \mathrm{~mm}$ phosphate buffer $\mathrm{pH} 7.2$, and then using $200 \mathrm{~m} l$ each of $50 \mathrm{~mm}$ phosphate buffer $\mathrm{pH} 6.0$ and the same buffer containing $0.5 \mathrm{M} \mathrm{NaCl}^{13}$. The flow rate was maintained at $30 \mathrm{ml} / \mathrm{hr}$, and $10 \mathrm{ml}$-fractions were collected and monitored at 280 nm.

Starch block electrophoresis Fraction $\mathrm{S}_{3}$, as separated by Sephadex gel filtration (Fig. 2), was dialyzed against $0.06 \mathrm{M}$ veronal buffer $\mathrm{pH} 8.6$ containing $0.1 \% 2$-mercaptoethanol, and electrophoresed for $48 \mathrm{hr}$ in a starch block column $(2 \times 5 \times 50 \mathrm{~cm})$ under a constant current of $20 \mathrm{~mA}$. After the run, filter strip was pressed onto the starch block, dried, and stained with amido black $10 \mathrm{~B}$, in order to locate the protein zones. The starch cakes corresponding to respective zones were scraped and extracted with water.

The albumin components thus isolated were finally concentrated by ultrafiltration, dialyzed against $0.033 \mathrm{M}$ Tris-borate buffer $\mathrm{pH} 8.5$, and subjected to the following analyses.

Methods of analysis Starch gel electrophoresis was performed after YamanaKA et $a .^{14)}$. Molecular weight was estimated by thin layer chromatography (TLC) in Se- 
phadex $\mathrm{G}-100^{13)}$. SDS-Polyacrylamide gel electrophoresis was carried out in 7.5 or $10 \%$ gels using bromophenol blue as the marker ${ }^{16)}$. Bovine serum albumin, ovalbumin, chymotrypsin, myoglobin, and cytochrome c (Mann Res. Lab.) were used as standard proteins. The free sulf hydryl group was determined by the DTNB $^{* 4}$ method ${ }^{17}$. Protein concentration was measured by the biuret method. The concentration of isolated albumin component was calculated by use of its specific extinction, which was determined by dry weight and the absorbance at $280 \mathrm{~nm}$.

The binding tests with bromophenol blue (BPB), hydroxyazobenzene carboxylic acid (HABA), and bromocresol green (BCG) were performed, referring to the method of SAITO ${ }^{18)}$, RUSTEIN et al. ${ }^{19)}$, and MIYADA et al. ${ }^{20)}$, respectively. In the binding tests with BPB, $0.1 \mathrm{ml}$ of $5 \%$ albumin, $2.0 \mathrm{~m} l$ of $0.1 \mathrm{M}$ phosphate buffer $\mathrm{pH} 7.2$, and $0.05 \mathrm{~m} l$ of $0.05 \%$ BPB (Tokyo Kasei Co.) were mixed, and the mixture was examined for the formation of albumin-BPB complex, spectrophotometrically and starch gel electrophoretically. With HABA, $0.2 \mathrm{ml}$ of $5 \%$ albumin, $1.6 \mathrm{~m} l$ of $0.14 \mathrm{M}$ phosphate buffer $\mathrm{pH} 6.2$, and $0.2 \mathrm{~m} l$ of 10 fold dilute of the HABA (Daiichi Pure Chemicals Co.) stock solution were mixed, and the amount of the bound dye was calculated from the increment of O. D. at $510 \mathrm{~nm}$ after RUSTEIN et al. ${ }^{19)}$. With BCG, $0.05 \mathrm{ml}$ of $5 \%$ albumin and $2.5 \mathrm{~m} l$ of 5 -fold dilute of the BCG (Tokyo Kasei Co.) stock solution ${ }^{20)}$ were mixed, and the amount of the bound dye was calculated from the increment of $O$. D. at $630 \mathrm{~nm}$. In the present paper, HABA- and BCG-binding capacities of each albumin were expressed for convenience by $E_{510 \mathrm{~nm}} \times$ $1,000 /$ protein concentration $(\mathrm{mg} / \mathrm{m} l)$, and $\mathrm{E}_{630 \mathrm{~nm}} \times 1,000 /$ protein concentration $(\mathrm{mg} / \mathrm{m} l)$, respectively. They will be referred to hereafter as HABA- and BCG-binding index.

The methemalbumin (MHA) forming ability of each albumin was examined essentially according to Bunn et al. ${ }^{21}$. Briefly, $1 \%$ methemoglobin (metHb) solution was prepared as usual from the hemolyzate of carp or rabbit red cells, and mixed with an equal volume of $10-15 \%$ albumin. The mixture was incubated at $37^{\circ} \mathrm{C}$ for $2 \mathrm{hr}$, and subjected to starch gel electrophoresis. After the run, the gel was sliced horizontally into two halves, one being stained with amido black $10 \mathrm{~B}$ and the other with benzidine. MHA bands were identified as usual by comparing both electropherograms.

Sevin ${ }^{* 5}$ esterase (EC 3.1.1.2) activity of albumin was analyzed essentially after CASIDA et al. ${ }^{22)}$. Briefly, $0.25 \mathrm{~m} l$ of $4 \%$ albumin, $0.5 \mathrm{ml}$ of $0.5 \mathrm{M}$ phosphate buffer $\mathrm{pH} 8.0$, and 0.25 $\mathrm{ml}$ of $4 \mathrm{~mm}$ Sevin (Union Carbide Co.) were mixed and incubated at $37^{\circ} \mathrm{C}$ for $20-60 \mathrm{~min}$. After the incubation, $0.2 \mathrm{ml}$ of $0.2 \%$ 4-aminoantipyrine and $0.2 \mathrm{~m} l$ of $0.8 \%$ ferricyanide were successively added to the mixture and gently shaken. After 5 min-standing, the mixture was made up to $3 \mathrm{~m} l$ with water. The dye formed was transferred into chloro-

*4 5, 5'-Dithiobis-(2-nitrobenzoic acid).

*5 1-Naphthyl $N$-methylcarbamate. 
form, treated with anhydrous sodium sulfate, and analyzed spectrophotometrically at $460 \mathrm{~nm}$.

\section{Results and Discussion}

Electrophoresis of plasma protein fractions In Fig. 1 are schematically shown the starch gel electropherograms of plasma protein fractions of carp and of rabbit for reference. In the case of rabbit, two components (bands 1 and 2) remained soluble at 1/2 saturation with ammonium sulfate, whereas a single one (band 1) regarded as albumin, remained at $2 / 3$ saturation. In the case of carp, five (bands 1-5) and four (bands 1-4) components

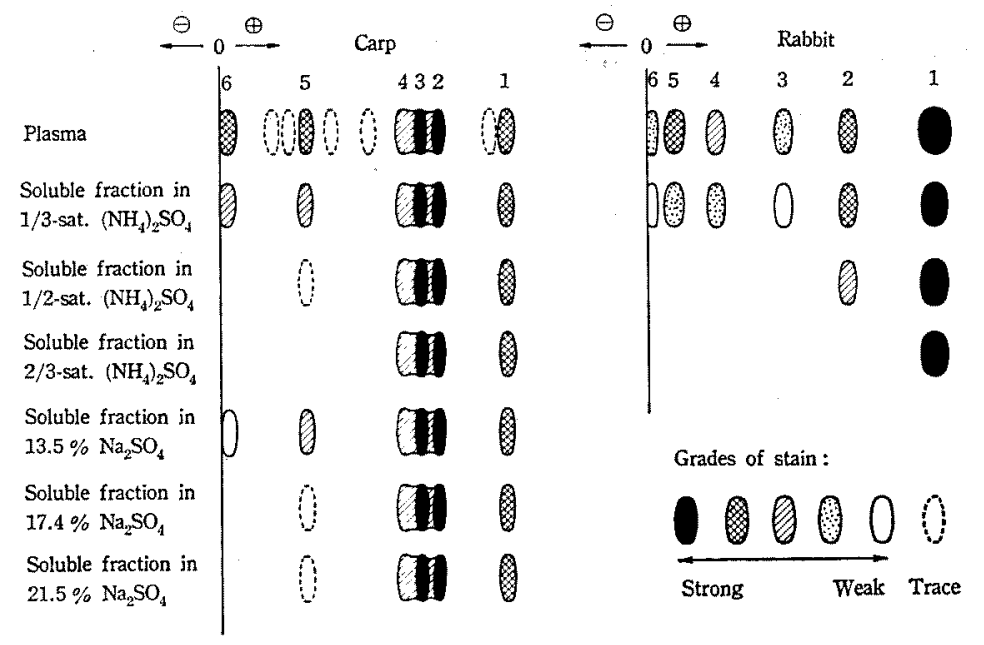

Fig. 1. Starch gel electropherograms of some plasma protein fractions from carp and rabbit.

remained soluble at $1 / 2$ and $2 / 3$ ammonium sulfate saturation, respectively. In addition, a rather diffuse band seemed to be present over a wide range between bands 2 and 4 . Essentially the same results were obtained when carp plasma was fractionated with sodium sulfate instead. From these results, it was concluded that carp plasma albumin is composed of at least four components, in a strong contrast to rabbit or other mam-

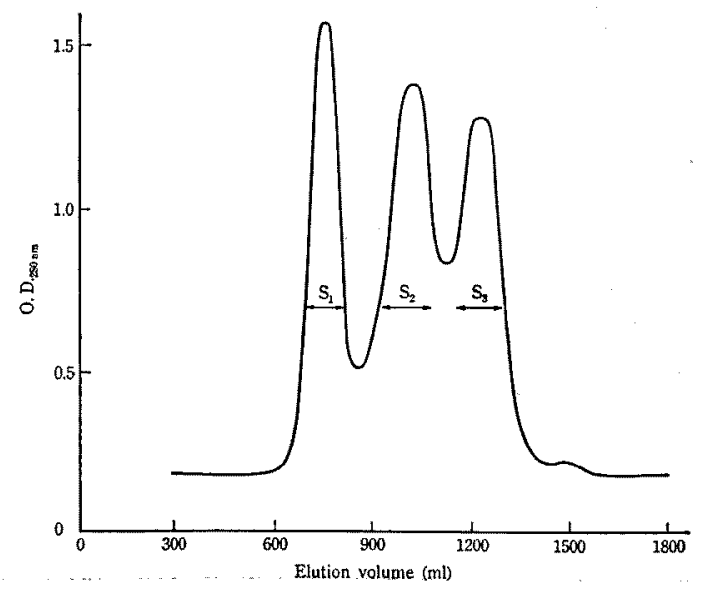

Fig. 2. Sephadex G-200 gel filtration of carp plasma protein. 
malian albumins which usually appear as a single component.

Isolation of albumin components A gel filtration profile of carp plasma protein is presented in Fig. 2. As seen in the figure, three peaks designated fractions (Fr.) $S_{1}, S_{2}$, and $S_{3}$, appeared. Fr. $S_{1}$ was discarded, since it was found to be non-albumin by electrophoresis described below. Ten-m $l$ fractions for each of Fr. $S_{2}$ and $S_{3}$, as indicated by both arrows, were combined and purified further: $\mathrm{Fr}$. $S_{2}$ was subjected to DEAE-cellulose column chromatography, resulting in separation into two components, $S_{2} D_{1}$ and $S_{2} D_{2}$, as shown in Fig. 3. The fractions for each component, as indicated by both arrows, were combined, concentrated by ultrafiltration, and dialyzed against $0.033 \mathrm{M}$ Tris-borate buffer $\mathrm{pH}$ 8.5. On the other hand, Fr. $\mathrm{S}_{3}$ was separated by starch block electrophoresis into three components designated $S_{3} E_{1}, S_{3} E_{2}$, and $S_{3} E_{3}$ in the order of decreasing mobility, as schematically given in Fig. 4. The three components were extracted from the respective starch blocks, concentrated, and dialyzed against the above buffer. Yields of components $\mathrm{S}_{2} \mathrm{D}_{1}$, $\mathrm{S}_{2} \mathrm{D}_{2}, \mathrm{~S}_{3} \mathrm{E}_{1}, \mathrm{~S}_{3} \mathrm{E}_{2}$, and $\mathrm{S}_{3} \mathrm{E}_{3}$, were roughly $0.5,0.5,0.3,0.3$, and $0.3 \mathrm{~g}$ respectively per $100 \mathrm{~m} l$ of carp plasma. In Fig. 5 are shown the electropherograms of the five components together with those of the plasma and Fr. $S_{1}$ for reference. By comparison of this figure with Fig. 1, components $S_{3} E_{1}, S_{3} E_{2}$, and $S_{3} E_{3}$ were recognized to correspond to albumin bands 1,2 , and 3 in Fig. 1, while Fr. $S_{1}$ non-albumin. In this connection, components $S_{2} D_{1}$ and $\mathrm{S}_{2} \mathrm{D}_{2}$ were supposed to correspond to the diffuse band ranging from band 2 to 4 , and

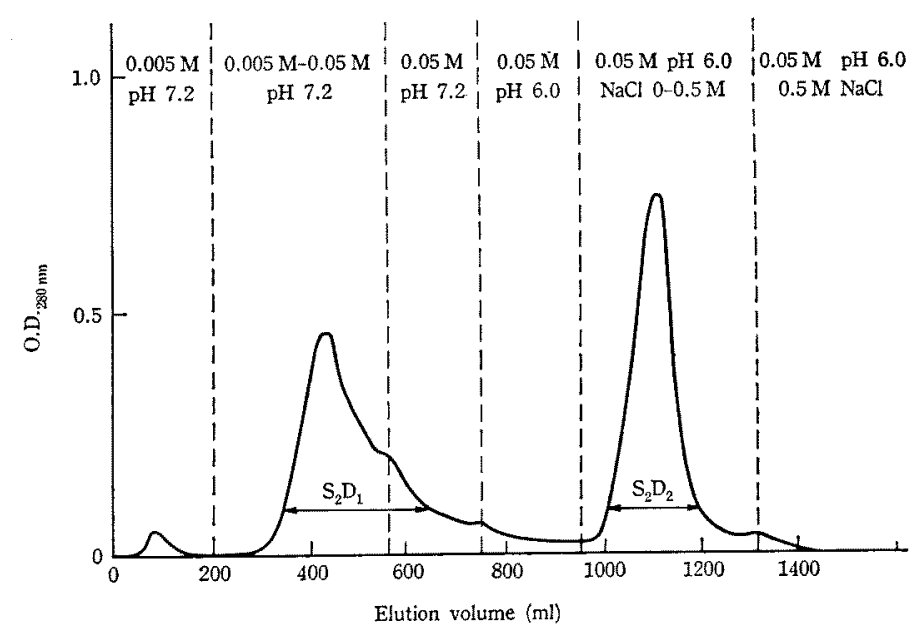

Fig. 3. DEAE-cellulose column chromatography of Fr. $S_{2}$, by a linear gradient using sodium phosphate buffers.

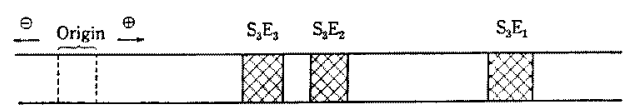

Fig. 4. Starch block electrophoresis of Fr. $S_{8}$. 


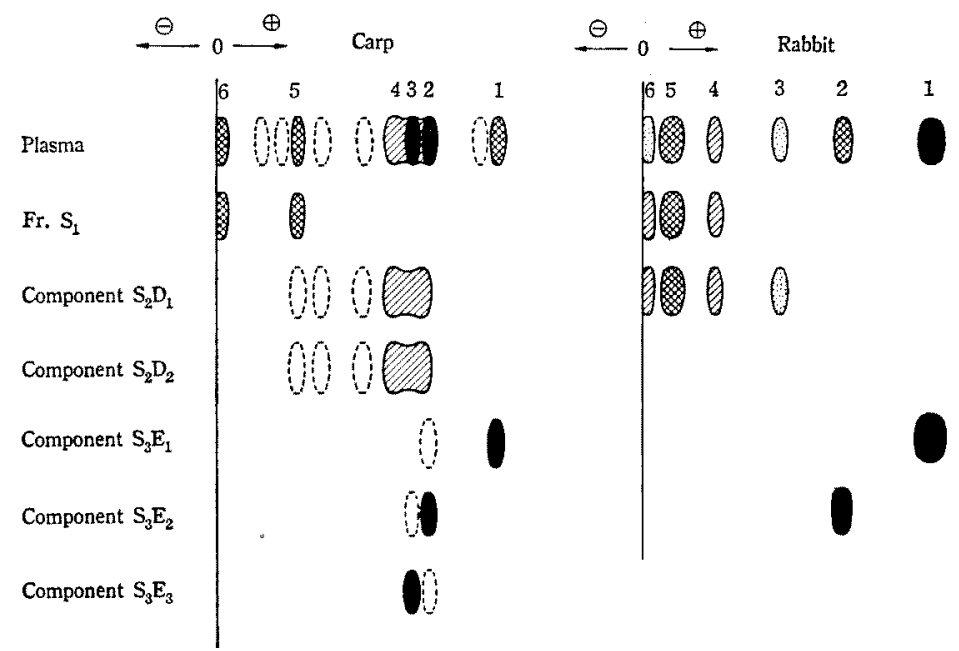

Fig. 5. Starch gel electropherograms of isolated albumin components of carp and rabbit.

were electrophoretically indistinguishable from each other under the conditions applied. As seen in Fig. 5, any of the five components was still contaminated with trace of one or two other components or foreign proteins. Due to scarcity of the samples available, however, they were analyzed without further purification. Rabbit albumin was obtained as a component roughly corresponding to $\mathrm{S}_{3} \mathrm{E}_{1}$ of carp albumin, as far as the method of isolation is concerned. The yield was about $3 \mathrm{~g} / 100 \mathrm{~m} l$ of the plasma.

Properties of carp albumin components The results obtained are collectively shown in Table 1.

Table 1. Properties of carp albumin components

\begin{tabular}{lrccccc}
\hline & \multicolumn{7}{c}{ Carp albumin component } & \multirow{2}{*}{$\begin{array}{c}\text { Rabbit } \\
\text { albumin }\end{array}$} \\
\cline { 2 - 6 } & $\mathrm{S}_{2} \mathrm{D}_{1}$ & \multicolumn{1}{c}{$\mathrm{S}_{2} \mathrm{D}_{2}$} & $\mathrm{~S}_{3} \mathrm{E}_{1}$ & $\mathrm{~S}_{2} \mathrm{E}_{2}$ & $\mathrm{~S}_{3} \mathrm{E}_{3}$ & \\
\hline Molecular weight & 145,000 & 145,000 & 58,000 & 71,000 & 71,000 & 69,000 \\
Subunit mol. wt. & 23,000 & 23,000 & - & - & - & - \\
$\mathrm{E}_{280 \mathrm{~m}}^{1 \%}$ & 6.29 & 6.55 & 6.01 & 11.0 & 12.5 & 6.76 \\
Color of aq. soln. & yellow & yellow & - & - & red & - \\
Free sulf hydryl groups & 0.5 & 0.5 & 0.3 & 2 & 1 & 0.7 \\
$\quad$ (mol/mol) & + & + & - & - & - & - \\
BPB-binding ability & 1.72 & 1.98 & 0.82 & 1.94 & 2.27 & 2.11 \\
HABA-binding index* & 12.8 & 15.2 & 18.9 & 27.1 & 21.6 & 25.3 \\
BCG-binding index* & + & + & - & ++ & \pm & ++ \\
MHA-forming ability & - & - & + & ++ & - & ++ \\
Sevin esterase activity & - & & & & & + \\
\hline
\end{tabular}

* Refer to the text for those definitions.

Molecular weight and subunit constitution By Sephadex-TLC and SDS-disc electrophoresis, it was demonstrated that components $S_{2} D_{1}$ and $S_{2} D_{2}$ have the same molecular weight of about 145,000 and are both composed of several subunit chains of a molecular 
weight of 23,000. On the other hand, the molecular weights of $S_{3} E_{1}, S_{3} E_{2}$, and $S_{3} E_{3}$ were estimated to be 50,000,67,000, and 67,000, respectively, by Sephadex-TLC. In SDS-disc electrophoresis, the three components presented the molecular weights of $58,000,71,000$, and 71,000 , in the above order, indicating that each of those components is a single polypeptide chain. These values are given as their molecular weights in Table 1. Rabbit albumin was confirmed to have a molecular weight of about 69,000 and to be composed of a single polypeptide, in agreement with some mammalian albumins ${ }^{11}$.

Absorption spectrum Each of the five albumin components exhibited an absorption maximum just at or around $280 \mathrm{~nm}$. Their specific extinction $\left(\mathrm{E}_{280 \mathrm{n}}^{1 \%}\right)$ markedly differed from each other. Rabbit albumin resembled carp $S_{2} D_{1}$ or $S_{2} D_{2}$ in this respect. The aq. solution of $S_{2} D_{1}, S_{2} D_{2}$, and $S_{3} E_{3}$ were colored: Yellow with the former two and red with the last. Their visible spectra are shown in Fig. 6. As judged from their spectra, $S_{2} D_{1}$ and $\mathrm{S}_{2} \mathrm{D}_{2}$ may be complexing with some bile pigments and/or carotenoids, whereas $\mathrm{S}_{3} \mathrm{E}_{3}$ may be a transferrin ${ }^{23)}$. No further examination has not yet been carried out with these three components.

Free sulfhydryl group The free sulf hydryl groups of components $\mathrm{S}_{3} \mathrm{E}_{2}$ and $\mathrm{S}_{3} \mathrm{E}_{3}$ were 2 and $1 \mathrm{~mol} / \mathrm{mol}$, respectively, and those of the other components less than $0.5 \mathrm{~mol} / \mathrm{mol}$. The value of rabbit albumin was $0.7 \mathrm{~mol} / \mathrm{mol}$. FANTL ${ }^{24 /}$ reported a value of $0.5-0.8 \mathrm{~mol} /$ mol for some mammalian albumins, suggesting their microheterogeneity.

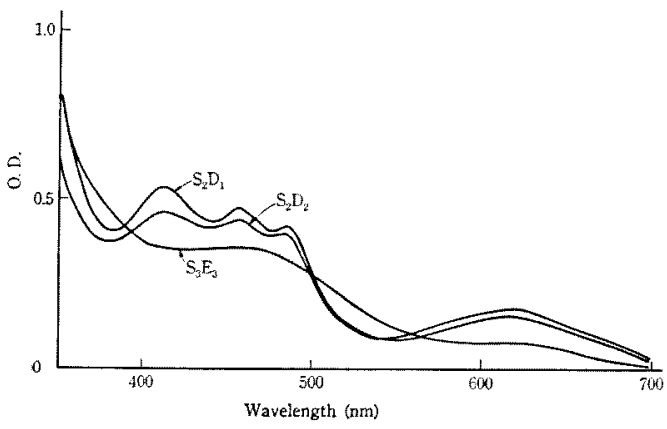

Fig. 6

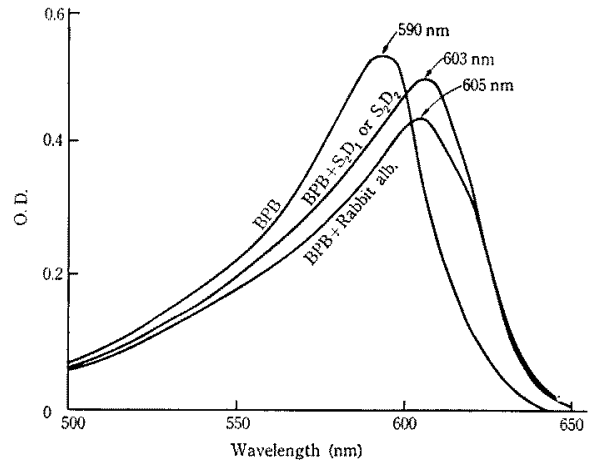

Fig. 7

Fig. 6. Absorption spectra of components $S_{2} D_{1}, S_{2} D_{2}$, and $S_{3} E_{3}$.

Fig. 7. Shift of absorption maximum of $B P B$ as caused by addition of component $S_{2} D_{1}$ (or $\mathrm{S}_{2} \mathrm{D}_{2}$ ) and rabbit albumin.

Binding with dyes 1) BPB As shown in Fig. 7, rabbit albumin shifted the absorption maximum of BPB from 590 to $605 \mathrm{~nm}$, indicating the formation of a complex. The same degree of shift was observed when component $S_{2} D_{1}$ or $S_{2} D_{2}$ was added instead, but not at all when the remaining three components were added. When $S_{2} D_{1}$ - or $S_{2} D_{2}$-BPB mixture was electrophoresed, a blue band of BPB-albumin complex appeared. It was 
noted that the blue band tended to fade away during the migration, resulting in a complete disappearance usually after $20 \mathrm{~min}$. This was not the case with rabbit albumin: Even after 90-min electrophoresis, the blue band was easily recognized, the fact that the binding of rabbit albumin with BPB is much stronger. No blue band was observed with the mixture with any other component.

2) $H A B A$ and $B C G$ As seen in Table 1, HABA-binding indexes of carp albumins were $0.82-2.27$, most of which were well comparable to that of rabbit albumin, 2.11.

On the other hand, BCG-binding indexes of carp albumins were ranging from 12.8 to 27.1, and that of rabbit albumin 25.3.

Both these dyes have been reported to bind specifically with albumin among plasma proteins $^{19,25)}$. To make it sure, the following two fractions of rabbit plasma protein were prepared and examined for the binding indexes with both dyes: Fr. A corresponding to band 2 and Fr. B corresponding to bands 3-6 in Fig. 1. According to the results, HABAbinding indexes of Fr. A and B were 1.36 and 2.20, respectively, and BCG-binding indexes of Fr. A and B, 4.2 and 17.5, respectively. These data clearly show that the binding with HABA or BCG is not so specific to albumin in the case of rabbit as well. Essentially the same results were obtained also with bovine plasma proteins.

Methemalbumin forming ability As shown in Table 1, all the carp albumin components except $\mathrm{S}_{3} \mathrm{E}_{1}$ exhibited a moderate to strong MHA forming ability under the conditions applied here. The results did not depend on the source of metHb. The MHA forming ability of $S_{3} E_{2}$ was found to match well that of rabbit albumin.

Sevin esterase activity Only components $\mathrm{S}_{3} \mathrm{E}_{1}$ and $\mathrm{S}_{3} \mathrm{E}_{2}$ showed this enzyme activity, as seen in Table 1 . The activity of the latter was qualitatively comparable to that of rabbit albumin for reference. AUGUSTINSSON ${ }^{26 /}$ reported the presence of aromatic ester esterase in the piscine plasma, indicating that the enzyme activity is generally lower than that of mammalian plasma. On the other hand, NYMAN ${ }^{27)}$ found by starch gel electrophoresis that the esterase activity of crucian carp plasma is located in 2-3 components which are close to our $S_{3} E_{1}$ and $S_{3} E_{2}$ in mobility.

As shown above, it was found that carp plasma albumin is composed of at least five components which differ from each other both in physico-chemical properties and in physiological functions such as dye-binding and Sevin esterase activity. It seems to deserve further research whether this holds true with other fishes as well. The carp seems to be the fish whose plasma proteins have so far been studied most intensively. Creyssel et $a l^{0)}$ reported that the fastest migrating protein in paper electrophoresis could be of comparatively high molecular weight, as judged from its gel filtration behavior. Recently, HARA $^{28)}$ has reported a similar observation. The protein component in question seems to correspond to our Fr. $S_{2}$. Incidentally, NAKAGAWA et al. ${ }^{9)}$ isolated a carp albumin by a similar procedure to that for our Fr. $\mathrm{S}_{2}$, and reported that it is a lipoprotein of a mole- 
cular weight of 150,000 , and is able to bind with BPB and BCG. They described that their albumin is composed of a single polypeptide chain, unlike our Fr. $\mathrm{S}_{2}$. The cause of this difference remains to be elucidated.

SILBERZAHN et al. ${ }^{7}$ ) found the presence of three hemopexic proteins in carp serum. It is not clear at present in what manners their proteins correspond to our albumin components possessing a MHA forming ability. They also isolated a transferrin, to which our component $\mathrm{S}_{3} \mathrm{E}_{3}$ may be related. On the other hand, NAGANo et al. ${ }^{8)}$ isolated in a highly pure state a carp serum protein which has the second fastest mobility in cellulose acetate electrophoresis. This protein was shown to have a molecular weight of 59,000, and to possess free sulfhydryl group at less than one $\mathrm{mol} / \mathrm{mol}$. We recognized in an experiment that our component $S_{3} E_{1}$ showing the fastest mobility in starch gel electrophoresis exhibits the second fastest mobility in cellulose acetate electrophoresis. From these facts, the protein purified by NaGano et al. ${ }^{8)}$ seems to account for a portion of our $\mathrm{S}_{3} \mathrm{E}_{1}$.

As indicated by PETERS ${ }^{29}$, the definition that plasma (or serum) albumin is a single major component of the fastest electrophoretic mobility, is not applicable to the lower vertebrates. The present results seem to support this view clearly. In this connection, WALLACE et al. ${ }^{30)}$ also disclosed, by comparing immunologically plasma albumins of various frogs that the difference between two given amphibians is often even wider than the average difference between the reptile and the bird. Making an attempt to characterize collectively the plasma protein of fish, $\mathrm{HARA}^{25)}$ found that the interspecific differences of plasma protein are unexpectedly large. The knowledge of piscine plasma albumin is still lacking or insufficient in various aspects. A study is now in progress on the MHA forming ability of some carp albumin components, and the results will be reported in the succeeding paper.

\section{Acknowledgements}

We wish to express our sincere thanks to the late Professor Yoshiro Hashimoto of our university for valuable suggestion and encouragement during the present study. Thanks are also due to Professor Chiaki SHImizu of our university and to Nozawaya Freshwater Fish Co. for providing carp plasma. The expenses of the present work were partly defrayed by a research fund granted from the Ministry of Education.

\section{References}

1) F. W. Putnam: In "The Protein" (ed. by H. Neurath), Vol. 3, Academic Press, New York, 1965, pp. 153-267.

2) T. Peters, Jr.: In "The Plasma Protein" (ed. by F. W. Putnam), Vol. 1, Academic Press, New York, 1975, pp. 57-131.

3) R. E. FeEneY and W. D. Brown: In "Chemical Zoology" (ed. by M. Florkin and B. T. SCheer), Vol. 8, Academic Press, New York, 1974, pp. 307-329. 
4) J. E. Harris: Comp. Biochem. Physiol., 48B, 389-399 (1974).

5) H. Perrier, J. P. Delcroix, C. Perrier, and J. Gras: ibid., 49B, 679-685 (1974).

6) R. Creyssel, P. Silberzahn, G. Richard, and Y. Manuel: Bull. Soc. Chim. Biol., 46, 149-159 (1964).

7) P. Silberzahn, G. B. Richard, and R. Creyssel: ibid., 49, 493-506 (1967).

8) H. Nagano, K. Hosaka, and R. Shukuya: Comp. Biochem. Physiol., 50B, 573-578 (1975).

9) H. Nakagawa, M. Kayama, and S. Asakawa: This Bull., 42, 677-685 (1976).

10) J. E. Cushing, G. J. Ridgway, and G. L. Durall: Biol. Bull., 113, 343-344 (1957).

11) P. E. Howe: J. Biol. Chem., 49, 109-113 (1921).

12) P. Flodin and J. Killander: Biochim. Biophys. Acta, 63, 403-410 (1962).

13) H. A. Sober, F. J. Gutter, M. M. WyCkoff, and E. A. Peterson: J. Am. Chem. Soc., 78, 756-763 (1956).

14) H. Yamanaka, K. Yamaguchi, and F. Matsuura: This Bull., 31, 827-832 (1965).

15) C. J. O. R. Morris: J. Chromatogr., 16, 167-175 (1963).

16) K. Weber and M. Osborn: J. Biol. Chem., 244, 4406-4412 (1969).

17) G. L. Ellman: Arch. Biochem. Biophys., 82, 70-77 (1959).

18) K. SAITo: Mem. Fac. Fish., Kagoshima Univ., 9, 1-15 (1960).

19) D. D. Rustein, E. F. Ingenito, and W. E. ReYnolds: J. Clin. Invest., 33, 211-221 (1954).

20) D. S. Miyada, V. Baysinger, S. Notrica, and R. M. Nakamura：Clin. Chem., 18, 52-56 (1972).

21) H. F. BUNn and J. H. JANDL: J. Biol. Chem., 243, 465-475 (1968).

22) J. E. Casida and K. B. Augustinsson: Biochim. Biophys. Acta, 36, 411-426 (1959).

23) P. AIsEN: J. Biol. Chem., 241, 1666-1671 (1966).

24) P. Fantl: Comp. Biochem. Physiol., 42B, 403-408 (1972).

25) F. L. RODKEY: Clin. Chem., 11, 478-487 (1965).

26) K. B. Augustinsson: Ann. N. Y. Acad. Sci., 94, 844-860 (1961).

27) L. NyMAN: Hereditas, 53, 117-126 (1965).

28) A. Hara: This Bull., 41, 105-113 (1975).

29) T. Peters, Jr.: In “The Plasma Protein" (ed. by F. W. Putnam), Vol. 1, Academic Press, New York, 1975, pp. 133-181.

30) D. G. Wallace and A. C. Wilson: J. Mol. Evol., 2, 72-86 (1972). 